\title{
Effect of temperature and nitrogen concentration on biomass composition of Heterochlorella luteoviridis
}

\author{
Tania MENEGOL ${ }^{1}$, Andressa Bacalau DIPRAT ${ }^{1}$, Eliseu RODRIGUES ${ }^{1}$, Rosane RECH $^{1 *}$
}

\begin{abstract}
The interest in microalga as a food supplement has grown due their high contents of carotenoids, polyunsaturated fatty acids and proteins. This study evaluated the effect of different temperatures $\left(22,27\right.$ or $\left.32{ }^{\circ} \mathrm{C}\right)$ and sodium nitrate concentrations $\left(12,24,36,48\right.$ or $60 \mathrm{mg} \mathrm{L}^{-1}$ of N-NO$\left.{ }_{3}\right)$ in culture medium on Heterochlorella luteoviridis biomass production and composition. The highest biomass concentration $\left(3.35 \mathrm{~g} \mathrm{~L}^{-1}\right)$ was observed at the highest $\mathrm{N}-\mathrm{NO}_{3}$ concentration. The $\mathrm{N}-\mathrm{NO}_{3}$ concentration positively affected protein, carbohydrate and carotenoids contents of biomass. On the other hand, cells cultured at the lowest $\mathrm{N}-\mathrm{NO}_{3}$ concentration showed a slight increment in lipid content. The major carotenoid was lutein $(30.7 \pm 1.4 \%$ of total carotenoids), and the polyunsaturated fatty acids were $37 \pm 2 \%$ of total fatty acids. Low temperature improved the biosynthesis of $\omega 3$ type fatty acids by lowering the $\omega 6: \omega 3$ ratio. Overall, our results indicate $H$. luteoviridis can yield high biomass concentration under autotrophic growth, resulting in a biomass rich in carotenoids, mainly lutein, and $\omega 3$ polyunsaturated fatty acids.
\end{abstract}

Keywords: nitrogen; temperature; lipids; omega-3; carotenoids; microalga.

Practical Application: Microalgae can be used as food supplement and is a vegan source of omega-3 fatty acids.

\section{Introduction}

Microalgae are photosynthetic microorganisms that require light energy and carbon dioxide $\left(\mathrm{CO}_{2}\right)$ for their growth and production of high value compounds, such as carotenoids and polyunsaturated fatty acids. Microalgae biomasses can also be rich in proteins, lipids and carbohydrates (Borowitzka, 1992; Markou \& Nerantzis, 2013; Metting \& Pyne, 1986; Pancha et al., 2014). Microalgae lipids contain important polyunsaturated fatty acids, such as linoleic acid (LA), a-linolenic acid (ALA), eicosapentaenoic acid (EPA) and docosahexaenoic acid (DHA) (Hultberg et al., 2014; Markou \& Nerantzis, 2013). All-trans-lutein (xanthophyll) and all-trans- $\beta$-carotene are among the major carotenoids found in microalgae biomass (Rodrigues et al., 2014).

The growing demand of natural foods has increased the interest on carotenoids as colorants by the food industry (Chacón-Lee \& González-Mariño, 2010; Jin et al., 2003; Sahu et al., 2013). In the last decades, several authors have studied carotenogenesis in order to improve carotenoid biosynthesis efficiency and evaluate microorganisms, such as microalgae, bacteria and cyanobacteria (Schroeder \& Johnson, 1995), fungi and yeast (Aksu \& Eren, 2005; Buzzini et al., 2005) to increase pigments production on an industrial scale. However, culture medium composition, such as carbon and nitrogen sources (Aksu \& Eren, 2005), and the presence of metals, salts and chemical agents (Buzzini et al., 2005) are factors that still need research in order to optimize the process of carotenoids production in different species of microorganisms. Some investigations have shown an increase in carotenoid content of Dunaliella salina cultured under several light intensities (Orset \& Young, 1999) and micronutrient stress, such as, iron, zinc and manganese (Saha et al., 2013).

Temperature plays an important role in microalgae metabolism, particularly in the lipids synthesis, which affects fatty acid composition (Renaud et al., 2002; Sushchik et al., 2003; Venkata Mohan \& Devi, 2014). Nitrogen is essential for protein and chlorophyll synthesis, which is another key factor that affects microalgae growth (Cheng et al., 2013). Nitrogen concentration limitation during cultivation is responsible for altering cellular metabolism and exerting a significant function in lipid synthesis accumulation in microalgae biomass, specially saturated and monounsaturated fatty acids (Converti et al., 2009; Olofsson et al., 2014).

In addition to specific factors of cultivation, the selection of microalgae is another important factor, because the biochemical and physiological responses to changes in the cultivation conditions vary according to specific species (Singh et al., 2015). The basic knowledge of algal physiology is important, since the success of algal biotechnology depends on choosing the right algae with the required properties for a specific product or culture conditions (Pulz \& Gross, 2004).

The microalga specie Chlorella luteoviridis was commercialized as food supplement in the European Union market prior to 1997, so it is not subject to the Novel Food Regulation (EC) No. 258/97 (Champenois et al., 2014). After a taxonomic revision, C. luteoviridis was recently reclassified as Heterochlorella luteoviridis 
(Neustupa et al., 2009). Considering that information on the metabolic versatility of microalgae Heterochlorella luteoviridis (former Chlorella luteoviridis) are few, this study investigated the effect of temperature and nitrogen concentration on biomass composition of $H$. luteoviridis, namely, proteins, lipids, carbohydrates and carotenoids.

\section{Materials and methods}

\subsection{Microalgae and cultivation condition}

The microalgae Heterochlorella luteoviridis BE002 was obtained from the culture collection of the Department of Marine Biology, Federal University Fluminense (Niterói, Rio de Janeiro, RJ, Brazil), where certified stocks are kept and can be requested. The cells were maintained in the Bioengineering Laboratory (ICTA/UFRGS) in f/2 medium (Guillard, 1975) at $22{ }^{\circ} \mathrm{C}$ in a germination chamber under a $12 / 12 \mathrm{~h}$ (light/dark) photoperiod. The inoculum $(240 \mathrm{~mL})$ was grown in rotatory shaker at the following conditions: $28^{\circ} \mathrm{C}, 14$ days, continuous illumination $5.0 \mathrm{klx}$ (equivalent to $70 \mu \mathrm{E} \mathrm{m}^{-2} \mathrm{~s}^{-1}$ ) and initial $\mathrm{pH} 8.5$.

The cultures were performed in flat-plate airlift photobioreactors (PBRs) with $2.4 \mathrm{~L}$ working volume (Kochem et al., 2014), aerated at $1 \mathrm{~L} \mathrm{~min}^{-1}$ of $\mathrm{CO}_{2}$-enriched air ( $1 \%$ volume fraction) and continuously illuminated at $18.0 \mathrm{klx}$ at the riser side by a panel of electronic lamps $(24 \times 13 \mathrm{~W}$ cool light, equivalent to $252 \mu \mathrm{E} \mathrm{m} \mathrm{m}^{-2} \mathrm{~s}^{-1}$ ). The microalga was grown in $\mathrm{f} / 2$ medium modified in its $\mathrm{NaNO}_{3}$ concentration according to a hexagonal experimental design (Doehlert, 1970) using two variables: temperature $\left(22,27\right.$ and $\left.32{ }^{\circ} \mathrm{C}\right)$ and $\mathrm{NaNO}_{3}$ content $\left(75,150,225,300\right.$ and $\left.375 \mathrm{mg} \mathrm{L}^{-1}\right)$, which contains $16.4 \%$ of nitrogen $\left(\mathrm{N}-\mathrm{NO}_{3}\right)$, corresponding to $12,24,36,48$ and $60 \mathrm{mg} \mathrm{L}^{-1}$ of $\mathrm{N}-\mathrm{NO}_{3}$, respectively. These values were chosen based on data previously reported (Jarenkow et al., 2015; Singh \& Singh, 2015).

During the cultivations, $1 \mathrm{~mL} \mathrm{~L}^{-1}$ of phosphate solution and $1 \mathrm{~mL} \mathrm{~L}^{-1}$ of trace metals solution, prepared according to Chagas et al. (2015), were added daily to the PBRs. All cultures were performed 4 times. During the cultures, the biomass concentration was measured by optical density at $750 \mathrm{~nm}\left(O D_{750}\right)$ (Chagas et al., 2015) and correlated with dry cell weight $(X)$ by the following Equation 1:

$$
X\left(\mathrm{~g} \mathrm{~L}^{-1}\right)=0.81 \times O D_{750}\left(R^{2}=0.979\right)
$$

At the end of 7 days, the biomass content of the PBRs was centrifuged $(10000 \times g, 10 \mathrm{~min})$, frozen, lyophilized and stored $\left(-22^{\circ} \mathrm{C}\right)$ for further analysis. Biomass productivity was determined as the biomass difference between the end of the growth phase and the beginning of the culture, divided by the respective cultivation time.

\subsection{Determination of lipids and fatty acid methyl esters (FAMEs)}

The total lipid content was measured by the method described by Bligh \& Dyer (1959) using $0.50 \mathrm{~g}$ of freeze-dried biomass. For FAME identification, the extracted lipids were methylated with a $14 \% \mathrm{BF}_{3}$-methanol solution at an ebullition temperature for 30 min under a $\mathrm{N}_{2}$ atmosphere following the method of
Joseph et al. (1992). The fatty acids were identified using gas chromatography (GC Model 2010, Shimadzu, Kyoto, Japan) equipped with automated sampler and injector, flame ionization detector and a capillary column of fused silica (SBL 100, Shimadzu, $30 \mathrm{~m} \times 0.25 \mathrm{~mm}$ i.d., $0.25 \mu \mathrm{m}$ film thickness). The solvent used was hexane, and the injector temperature was set at $240{ }^{\circ} \mathrm{C}$. The carrier gas was $\mathrm{H}_{2}$ at a constant flow of $1 \mathrm{~mL} \mathrm{~min}^{-1}$. The flame ionization detector (FID) was set at $260{ }^{\circ} \mathrm{C}$ with a $\mathrm{H}_{2}$ flow of $40 \mathrm{~mL} \mathrm{~min}^{-1}$ and air flow at $400 \mathrm{~mL} \mathrm{~min}^{-1}$. The oven temperature was set at $50{ }^{\circ} \mathrm{C}$ for $1 \mathrm{~min}$ and then increased to $250{ }^{\circ} \mathrm{C}$ at a

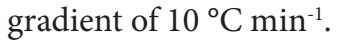

The identification of each fatty acid was performed comparing the retention time with a standard mixture of fatty acid methyl esters (FAME-MIX 37 standard Sigma ${ }^{\circledR}$ ). Moreover, the identification was confirmed by the injection of the sample in a gas chromatography with mass spectrometer detector (GC-MS Model QP2010, Shimadzu, Kyoto, Japan). The quantification of the fatty acids was performed according to the AOAC method (American Oil Chemists' Society, 1997).

\subsection{Determination of carbohydrates and proteins}

The carbohydrate content was measured after acid hydrolysis of the microalgae biomass. The supernatant was used for carbohydrate measurement by the phenol-sulfuric acid method (DuBois et al., 1956). The protein solution was prepared as described by Li et al. (2015) with modifications. Firstly, the biomass was hydrated overnight at with $5 \mathrm{~mL}$ of distilled water $\left(T<5^{\circ} \mathrm{C}\right)$. The biomass-water suspension was centrifuged $(3000 \times g, 10 \mathrm{~min})$ and $1 \mathrm{~mL}$ of $\mathrm{NaOH}(1 \mathrm{~N})$ was added to the pellet, mixed using a vortex, and heated to $95^{\circ} \mathrm{C}$ for $20 \mathrm{~min}$. The alkaline lyse was neutralized with $0.5 \mathrm{~mL}$ of $\mathrm{HCl}(1.6 \mathrm{~N})$. The samples were cooled to room temperature and centrifuged $(3000 \times g, 10 \mathrm{~min})$. The protein content was measured in the supernatant by the Lowry method (Lowry et al., 1951). The calibration curve was prepared using BSA dissolved in distilled water.

\subsection{Determination of carotenoids}

The extraction was conducted according to the adapted method described by Mandelli et al. (2012) using $20 \mathrm{mg}$ of freeze-dried biomass. To determine the carotenoids' composition, the dry extract was dissolved in $\mathrm{MeOH} / \mathrm{MTBE}(70: 30, \mathrm{v} / \mathrm{v})$ and analyzed by HPLC-DAD-MS ${ }^{2}$. The carotenoids were separated on a $\mathrm{C}_{30}$ YMC column $(5 \mu \mathrm{m}, 250 \times 4.6 \mathrm{~mm}$ i.d.) (Waters, Wilmington, USA) at a flow rate of $0.9 \mathrm{~mL} \mathrm{~min}^{-1}$ and column temperature at $29{ }^{\circ} \mathrm{C}$ using a linear gradient mobile phase of methanol/MTBE from 95:5 to $70: 30$ in $30 \mathrm{~min}$, followed by $50: 50$ in $20 \mathrm{~min}$ and maintaining this proportion for $15 \mathrm{~min}$ (Rodrigues et al., 2014). The carotenoids were identified in an HPLC (Shimadzu, Kyoto, Japan) equipped with binary pump (model LC-20AD) and an online degasser connected in series with a diode array detector (DAD) and a mass spectrometer (MS) with an iron trap analyzer and atmospheric pressure chemical ionization (APCI) source (Bruker Daltonics, Esquire model 6000, Bremen, Germany). The HPLC-DAD-MS² parameters were set using the same conditions as previously described by De Rosso \& Mercadante (2007). The quantification of carotenoids was performed using a Waters HPLC 2695 series system (Wilmington, EUA) 
equipped with a diode array detector (Waters 2998 dual series). The carotenoids were quantified using a nine-point analytical curve of all-trans- $\beta$-carotene ( 0.13 to $\left.15 \mathrm{mg} \mathrm{L}^{-1}\right)$. The analytical curve was linear $\left(R^{2}=0.998\right)$, the detection limit was $0.9 \mathrm{mg} \mathrm{L}^{-1}$ and the quantification limit was $2.8 \mathrm{mg} \mathrm{L}^{-1}$.

\subsection{Statistical analysis}

The effects of variables (temperature and nitrogen) on each response were evaluated by multiple linear regression using a quadratic model and validated by analysis of variance (ANOVA). Fatty acids composition was analysed using principal component analysis. The results were also compared using the Tukey test at a 5\% significance level. All statistical analyses were performed using Statistic 12.0 (StatSoft, Inc.).

\section{Results and discussion}

\subsection{Biomass}

The biomass concentration was only affected by the nitrogen concentration $\left(p=2.9 \times 10^{-9}, R^{2}=0.75\right)$. The culture with the highest nitrogen concentration presented the highest final biomass $\left(3.35 \mathrm{~g} \mathrm{~L}^{-1}\right)$, which was 2.3 -fold higher than the biomass of the culture with the lowest nitrogen concentration $\left(1.43 \mathrm{~g} \mathrm{~L}^{-1}\right)$ (Figure 1a). According to Juneja et al. (2013), nitrogen deficiency leads to nutritional changes associated with stress conditions, causing a decrease on biomass formation.

The biomass concentration of $3.35 \mathrm{~g} \mathrm{~L}^{-1}$ is considered high for autotrophic culture $\left(\mathrm{CO}_{2}\right.$ as sole carbon source) and was achieved in a relatively short time (7 days), biomass productivity of $\left.0.48 \mathrm{~g} \mathrm{~L}^{-1} \mathrm{~d}^{-1}\right)$. The high productivity can be attributed to the innate characteristics of $H$. luteoviridis, which have been poorly explored up to now, but they can also be attributed to the photobioreactor performance, which already allowed high specific growth rates using other microalgae species (Kochem et al., 2014). Similar biomass concentrations using autotrophic cultures were achieved with other Chlorella species, however, with lower productivities. Autotrophic culture is the usual condition to grow microalgae (Chen et al., 2011; Perez-Garcia \& Bashan, 2015), although Chlorella vulgaris biomass increased 4.8 times in an heterotrophic culture (using organic carbon) when compared to an autotrophic culture (Perez-Garcia et al., 2010). However, heterotrophic cultures require costly carbon, which raises the long-term operation cost of the process (Perez-Garcia \& Bashan, 2015). Autotrophic cultures contribute to a reduction of the greenhouse effect by using $\mathrm{CO}_{2}$ as the carbon source, and the optimization of nutrients and cultures conditions can increase biomass productivity.

\subsection{Biomass composition: carbohydrates, proteins and lipids}

The composition of $H$. luteoviridis BE002 biomass was affected by growth conditions. Nitrogen concentration and temperature affected both the carbohydrate $\left(p=3.7 \times 10^{-5}, R^{2}=0.68\right)$ and protein $\left(p=5.8 \times 10^{-9}, R^{2}=0.87\right)$ contents of the biomass. At low temperature, the nitrogen concentration did not affect the carbohydrate content, while at high temperatures, increases in nitrogen concentration increased carbohydrate content (Figure $2 \mathrm{a}$ ). The protein content also increased with the nitrogen concentration; however, this behavior was stronger at low temperatures (Figure $2 \mathrm{~b}$ ). The highest protein content $\left(138 \mathrm{mg} \mathrm{g}^{-1}\right)$ was found in the culture with the highest nitrogen concentration ( $60 \mathrm{mg} \mathrm{L}^{-1} \mathrm{~N}-\mathrm{NO}_{3}$ ). This value was $45 \%$ higher than that observed in the culture with the lowest nitrogen concentration $\left(12 \mathrm{mg} \mathrm{L}^{-1} \mathrm{~N}-\mathrm{NO}_{3}\right)$ when both were at $27^{\circ} \mathrm{C}$. The effect of the temperature was less pronounced and dependent of nitrogen concentration. At low nitrogen concentration, the protein content increased with temperature, while for high nitrogen concentration, the protein content decreased as the temperature increased.

Similar results were found for other microalgae genus, such as Chlorella zofingiensis, Isochrysis sp. and Prymnesiophyte
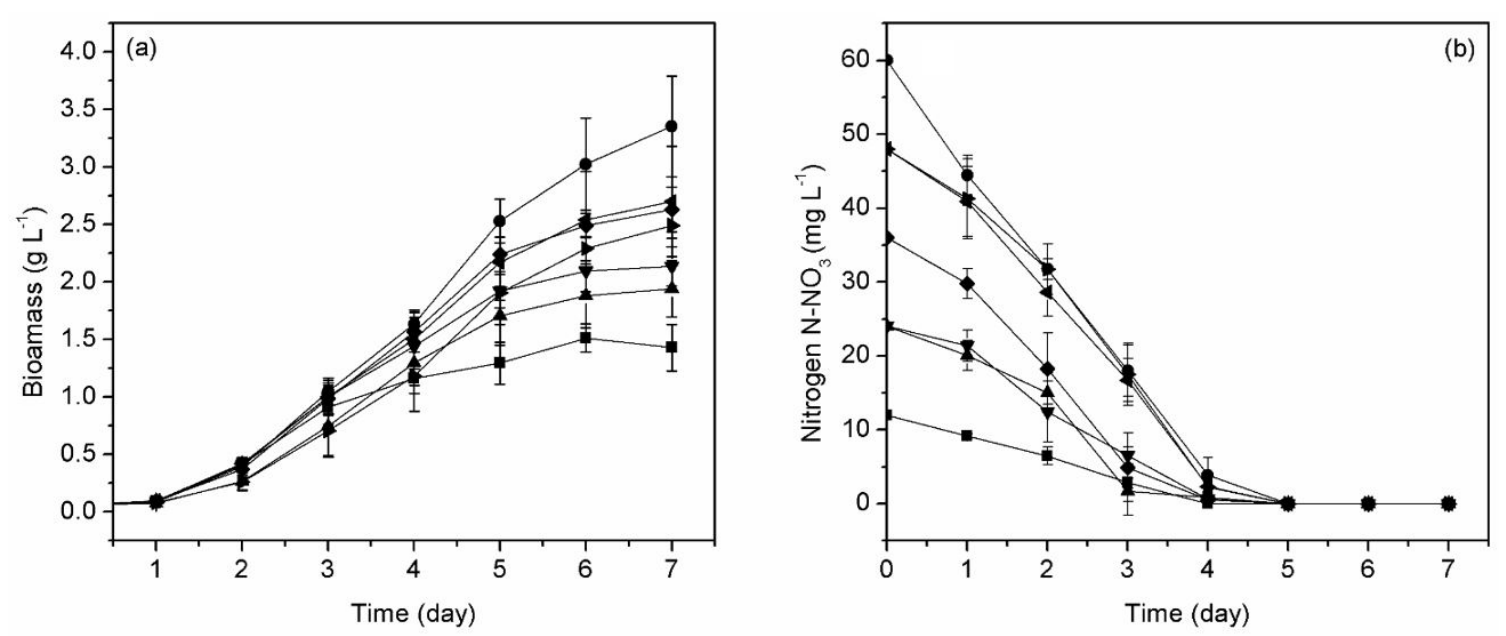

Figure 1. Kinetics of (a) biomass growth and (b) nitrogen consumption of H. luteoviridis cultured under different temperatures and initial

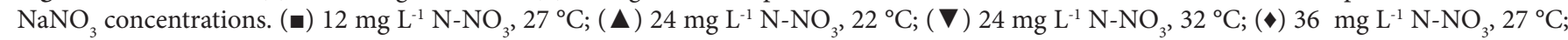

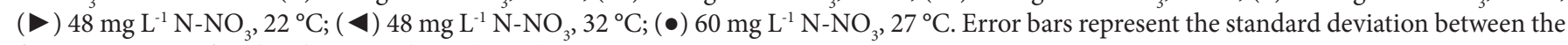
four repetitions of each culture condition $(n=4)$. 
(a)

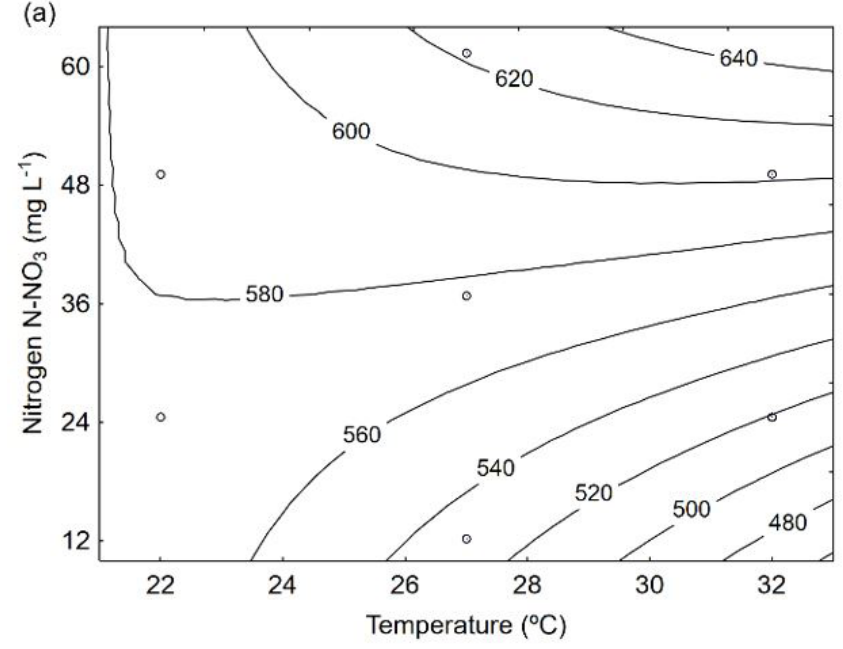

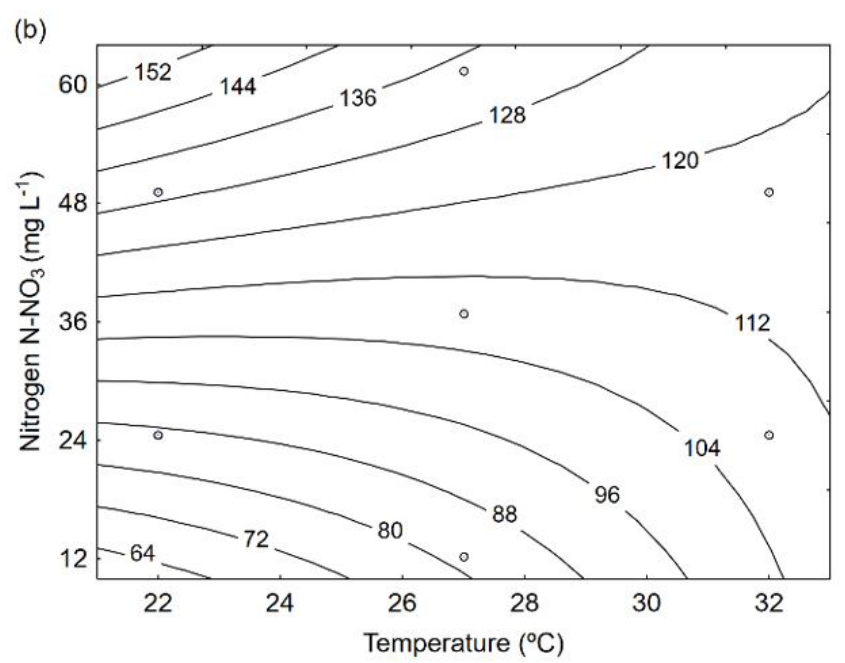

Figure 2. Response surfaces for (a) total carbohydrate $\left(\mathrm{mg} \mathrm{g}^{-1}\right)$ and (b) protein $\left(\mathrm{mg} \mathrm{g}^{-1}\right)$ contents in the biomass of H. luteoviridis grown under different temperatures and nitrogen concentrations.

(NT19). The reduction in the protein content of Isochrysis sp. (T.ISO) and Prymnesiophyte (NT19) biomasses was attributed to elevated temperatures $\left(33{ }^{\circ} \mathrm{C}\right.$ to $\left.35^{\circ} \mathrm{C}\right)$, and this result may be associated to the breakdown of protein structure and interference with enzyme regulators (Renaud et al., 2002). Nitrogen is essential for protein synthesis (Ikaran et al., 2015; Juneja et al., 2013; Zhu et al., 2014), so the decrease in protein synthesis by microalga cells is a natural response to nitrogen starvation (Zhu et al., 2015).

The synthesis of carbohydrates was also affected by nitrogen concentration. Similar to protein, the highest carbohydrate content $\left(631 \mathrm{mg} \mathrm{g}^{-1}\right)$ was observed in the culture with the highest nitrogen concentration $\left(60 \mathrm{mg} \mathrm{L}^{-1} \mathrm{~N}-\mathrm{NO}_{3}\right)$ at $27^{\circ} \mathrm{C}$. This value was $19.3 \%$ higher than that observed in the cultivation with the lowest nitrogen concentration $\left(529 \mathrm{mg} \mathrm{g}^{-1}\right)$ at the same temperature. These results are different than those found by other authors, who reported an increase in carbohydrate content of microalgae biomass culture under nitrogen starvation (Pancha et al., 2014).

Microalgae metabolism under nitrogen starvation decreases protein biosynthesis (Zhu et al., 2015) and directs it to lipid and carbohydrate biosynthesis (Fan et al., 2012; Ho et al., 2012). As carbohydrate synthesis requires less energy, carbohydrates are synthesized before lipids in a rapid response to environmental stress (Zhu et al., 2014). However, after a long period under nitrogen starvation, photosynthesis efficiency decreases, and cells start to metabolize carbohydrates as energy and carbon sources (Wang et al., 2014). This may explain the lower carbohydrate content in cultures with low nitrate concentrations, since in these cultures, nitrogen reached zero at about $72 \mathrm{~h}$ of culture (Figure $1 \mathrm{~b}$ ) and persisted longer under nitrogen stress compared to cultures with high nitrate concentration, where nitrogen reached zero between $96 \mathrm{~h}$ and $120 \mathrm{~h}$.

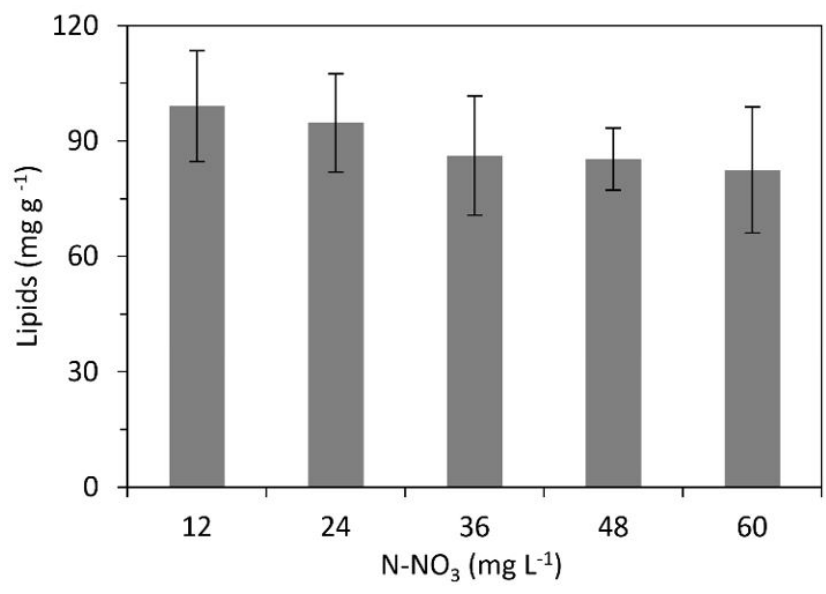

Figure 3. Lipid content in biomass of $H$. luteoviridis grown under different of nitrogen concentrations. Error bars represent the standard deviation between the four repetitions of each culture condition $(n=4)$.

Persisting longer under nitrogen starvation during microalgae cultivation can lead to high lipid synthesis. A study demonstrated that the lipid synthesis rate started to increase after $120 \mathrm{~h}$ nitrogen starvation (Zhu et al., 2014). In our study, the lipid content of biomass decreased with increased nitrogen concentration ( $p=0.0016, R^{2}=0.70$, Figure 3 ), ranging between $82.5 \mathrm{mg} \mathrm{g}^{-1}$ and $99.1 \mathrm{mg} \mathrm{g}^{-1}$ as nitrogen decreased from to $60 \mathrm{mg} \mathrm{L}^{-1}$ to $12 \mathrm{mg} \mathrm{L}^{-1} \mathrm{~N}-\mathrm{NO}_{3}$ (Figure 3). This negative effect of nitrogen concentration on lipid synthesis by microalgae is well described in the literature (Converti et al., 2009; Juneja et al., 2013; Pancha et al., 2014). The temperature showed no effect on lipid synthesis by $H$. luteoviridis BE002. However, a study with Chlorella vulgaris showed a $40 \%$ decrease on lipid content in the biomass when temperature increased from 25 to $30{ }^{\circ} \mathrm{C}$ (Converti et al., 2009). 


\subsection{Identification and quantification of lipid fraction}

The lipid fraction was characterized by the identification and quantification of carotenoids and fatty acids.

\section{Carotenoids}

Eleven carotenoids were identified in $H$. luteoviridis biomass (Table 1, Appendix A: Figure A1). The major carotenoids were all-trans-lutein, all-trans- $\alpha$-carotene, all-trans- $\beta$-carotene and all-trans-zeaxanthin. Both nitrogen concentration and temperature affected the content of carotenoids in the biomass. The highest carotenoid content of the biomass $\left(2.47 \mathrm{mg} \mathrm{g}^{-1}\right)$ was achieved in culture with the highest nitrogen concentration $\left(60 \mathrm{mg} \mathrm{L}^{-1} \mathrm{~N}-\mathrm{NO}_{3}\right.$ at $27^{\circ} \mathrm{C}$ ). It was 1.5 -fold higher than the carotenoid content in the culture with standard medium $\left(12 \mathrm{mg} \mathrm{L}^{-1}\right.$ of $\left.\mathrm{N}-\mathrm{NO}_{3}\right)$.
Nitrogen starvation interferes on carotenoid accumulation. There may be a change in the balance of enzymes that leads to a change in the synthesis of chlorophyll and, therefore, an increase in carotenoids (Christaki et al., 2013; Juneja et al., 2013).

The carotenoids were separated into two groups: xanthophylls and carotenes. The content of the xanthophylls increased linearly with nitrogen concentration and slightly decreased with temperature $\left(p=3.6 \times 10^{-6}, R^{2}=0.70\right.$, Figure $\left.4 \mathrm{a}\right)$, whereas the content of the carotenes was not affected by temperature. The content of the carotenes increased with nitrogen concentration $\left(p=6.1 \times 10^{-7}, R^{2}=0.74\right)$, and the highest contents were in the range of $36 \mathrm{mg} \mathrm{L}^{-1}$ to $60 \mathrm{mg} \mathrm{L}^{-1} \mathrm{~N}-\mathrm{NO}_{3}$ (Figure $4 \mathrm{~b}$ ).

The highest values found for all-trans-a-carotene and all-trans- $\beta$-carotene contents were $0.40 \mathrm{mg} \mathrm{g}^{-1}$ and $0.39 \mathrm{mg}$

Table 1. Composition of carotenoids $\left(\mathrm{mg} \mathrm{g}^{-1}\right)$ H. luteoviridis grown under different temperatures and nitrogen concentrations.*

\begin{tabular}{|c|c|c|c|c|c|c|c|}
\hline Temperature $\left({ }^{\circ} \mathrm{C}\right)$ & 27 & 27 & 22 & 32 & 32 & 22 & 27 \\
\hline Nitrogen $\left(\mathrm{mg} \mathrm{L}^{-1}\right)$ & 12 & 60 & 24 & 24 & 48 & 48 & 36 \\
\hline all-trans-violaxanthin & $0.03 \pm 0.01^{\mathrm{c}}$ & $0.11 \pm 0.05^{\mathrm{ab}}$ & $0.03 \pm 0.01^{\mathrm{c}}$ & $0.05 \pm 0.01^{\mathrm{bc}}$ & $0.13 \pm 0.04^{\mathrm{a}}$ & $0.06 \pm 0.02^{\mathrm{bc}}$ & $0.08 \pm 0.01^{\mathrm{abc}}$ \\
\hline cis-violaxanthin & $0.04 \pm 0.00^{\mathrm{d}}$ & $0.11 \pm 0.01^{\mathrm{ab}}$ & $0.10 \pm 0.02^{\mathrm{abc}}$ & $0.07 \pm 0.01^{\mathrm{cd}}$ & $0.12 \pm 0.03^{\mathrm{a}}$ & $0.09 \pm 0.02^{\mathrm{abc}}$ & $0.08 \pm 0.01^{b c}$ \\
\hline 9-cis-violaxanthin & $0.02 \pm 0.01^{\mathrm{a}}$ & $0.02 \pm 0.01^{\mathrm{a}}$ & $0.02 \pm 0.00^{\mathrm{a}}$ & $0.01 \pm 0.00^{\mathrm{a}}$ & $0.02 \pm 0.01^{\mathrm{a}}$ & $0.02 \pm 0.00^{\mathrm{a}}$ & $0.02 \pm 0.00^{\mathrm{a}}$ \\
\hline 13-cis-lutein & $0.05 \pm 0.01^{\mathrm{b}}$ & $0.05 \pm 0.01^{\mathrm{b}}$ & $0.05 \pm 0.01^{\mathrm{b}}$ & $0.06 \pm 0.01^{\mathrm{b}}$ & $0.10 \pm 0.01^{\mathrm{a}}$ & $0.07 \pm 0.01^{\mathrm{b}}$ & $0.10 \pm 0.01^{\mathrm{a}}$ \\
\hline 13'-cis-lutein & $0.02 \pm 0.00^{\mathrm{b}}$ & $0.03 \pm 0.00^{\mathrm{a}}$ & $0.02 \pm 0.00^{\mathrm{a}}$ & $0.02 \pm 0.00^{\mathrm{b}}$ & $0.02 \pm 0.00^{\mathrm{a}}$ & $0.03 \pm 0.00^{\mathrm{a}}$ & $0.02 \pm 0.00^{\mathrm{ab}}$ \\
\hline all-trans-lutein & $0.44 \pm 0.06^{\mathrm{b}}$ & $0.76 \pm 0.06^{\mathrm{a}}$ & $0.71 \pm 0.14^{\mathrm{a}}$ & $0.61 \pm 0.09^{\mathrm{ab}}$ & $0.77 \pm 0.09^{\mathrm{a}}$ & $0.70 \pm 0.13^{\mathrm{a}}$ & $0.65 \pm 0.05^{\mathrm{a}}$ \\
\hline all-trans-zeaxanthin & $0.24 \pm 0.02^{\mathrm{b}}$ & $0.35 \pm 0.02^{\mathrm{a}}$ & $0.36 \pm 0.04^{\mathrm{a}}$ & $0.23 \pm 0.02^{\mathrm{b}}$ & $0.19 \pm 0.01^{\mathrm{b}}$ & $0.35 \pm 0.01^{\mathrm{a}}$ & $0.19 \pm 0.02^{\mathrm{b}}$ \\
\hline cis-zeaxanthin & $0.01 \pm 0.00^{c}$ & $0.02 \pm 0.00^{\mathrm{ab}}$ & $0.01 \pm 0.00^{\mathrm{abc}}$ & $0.01 \pm 0.00^{\mathrm{bc}}$ & $0.02 \pm 0.00^{\mathrm{bc}}$ & $0.02 \pm 0.00^{\mathrm{a}}$ & $0.01 \pm 0.00^{b c}$ \\
\hline 15 -cis- $\beta$-carotene & $0.03 \pm 0.00^{\mathrm{a}}$ & $0.03 \pm 0.00^{\mathrm{a}}$ & $0.03 \pm 0.00^{\mathrm{a}}$ & $0.03 \pm 0.00^{\mathrm{a}}$ & $0.04 \pm 0.01^{\mathrm{a}}$ & $0.03 \pm 0.00^{\mathrm{a}}$ & $0.03 \pm 0.00^{\mathrm{a}}$ \\
\hline all-trans- $\alpha$-carotene & $0.24 \pm 0.04^{\mathrm{d}}$ & $0.35 \pm 0.03^{\mathrm{ab}}$ & $0.27 \pm 0.08^{\mathrm{cd}}$ & $0.30 \pm 0.05^{\mathrm{bcd}}$ & $0.40 \pm 0.04^{\mathrm{a}}$ & $0.27 \pm 0.03^{\mathrm{bcd}}$ & $0.32 \pm 0.04^{\mathrm{bc}}$ \\
\hline 13-cis- $\beta$-caroteno & $0.07 \pm 0.01^{\mathrm{d}}$ & $0.14 \pm 0.01^{\mathrm{a}}$ & $0.12 \pm 0.04^{\mathrm{ab}}$ & $0.07 \pm 0.01^{\mathrm{cd}}$ & $0.10 \pm 0.00^{\mathrm{bc}}$ & $0.12 \pm 0.01^{\mathrm{ab}}$ & $0.13 \pm 0.02^{\mathrm{ab}}$ \\
\hline all-trans- $\beta$-carotene & $0.30 \pm 0.03^{\mathrm{b}}$ & $0.36 \pm 0.03^{\mathrm{ab}}$ & $0.35 \pm 0.06^{\mathrm{ab}}$ & $0.33 \pm 0.04^{\mathrm{ab}}$ & $0.39 \pm 0.02^{\mathrm{a}}$ & $0.35 \pm 0.03^{\mathrm{ab}}$ & $0.39 \pm 0.02^{\mathrm{a}}$ \\
\hline 9-cis- $\beta$-carotene & $0.13 \pm 0.02^{c}$ & $0.18 \pm 0.00^{\mathrm{ab}}$ & $0.18 \pm 0.05^{\mathrm{ab}}$ & $0.14 \pm 0.02^{\mathrm{bc}}$ & $0.15 \pm 0.00^{\mathrm{abc}}$ & $0.18 \pm 0.04^{\mathrm{ab}}$ & $0.19 \pm 0.03^{\mathrm{a}}$ \\
\hline Total xantophylls & $0.84 \pm 0.09^{c}$ & $1.44 \pm 0.11^{\mathrm{a}}$ & $1.29 \pm 0.15^{\mathrm{ab}}$ & $1.06 \pm 0.11^{\mathrm{bc}}$ & $1.38 \pm 0.06^{\mathrm{ab}}$ & $1.33 \pm 0.08^{\mathrm{ab}}$ & $1.16 \pm 0.09^{\mathrm{abc}}$ \\
\hline Total carotenes & $0.76 \pm 0.09^{\mathrm{a}}$ & $1.06 \pm 0.04^{\mathrm{a}}$ & $0.94 \pm 0.20^{\mathrm{a}}$ & $0.87 \pm 0.09^{\mathrm{a}}$ & $1.08 \pm 0.05^{\mathrm{a}}$ & $0.95 \pm 0.07^{\mathrm{a}}$ & $1.06 \pm 0.04^{\mathrm{a}}$ \\
\hline Total carotenoids & $1.59 \pm 0,17^{\mathrm{b}}$ & $2.50 \pm 0.10^{\mathrm{a}}$ & $2.23 \pm 0.35^{\mathrm{a}}$ & $1.93 \pm 0.18^{\mathrm{ab}}$ & $2.46 \pm 0.10^{\mathrm{a}}$ & $2.28 \pm 0.15^{\mathrm{a}}$ & $2.22 \pm 0.06^{\mathrm{ab}}$ \\
\hline
\end{tabular}

${ }^{*}$ Mean \pm standard deviation; means with the same letter in the same line does not present significant difference by Tukey test at a significance level of $5 \%$.
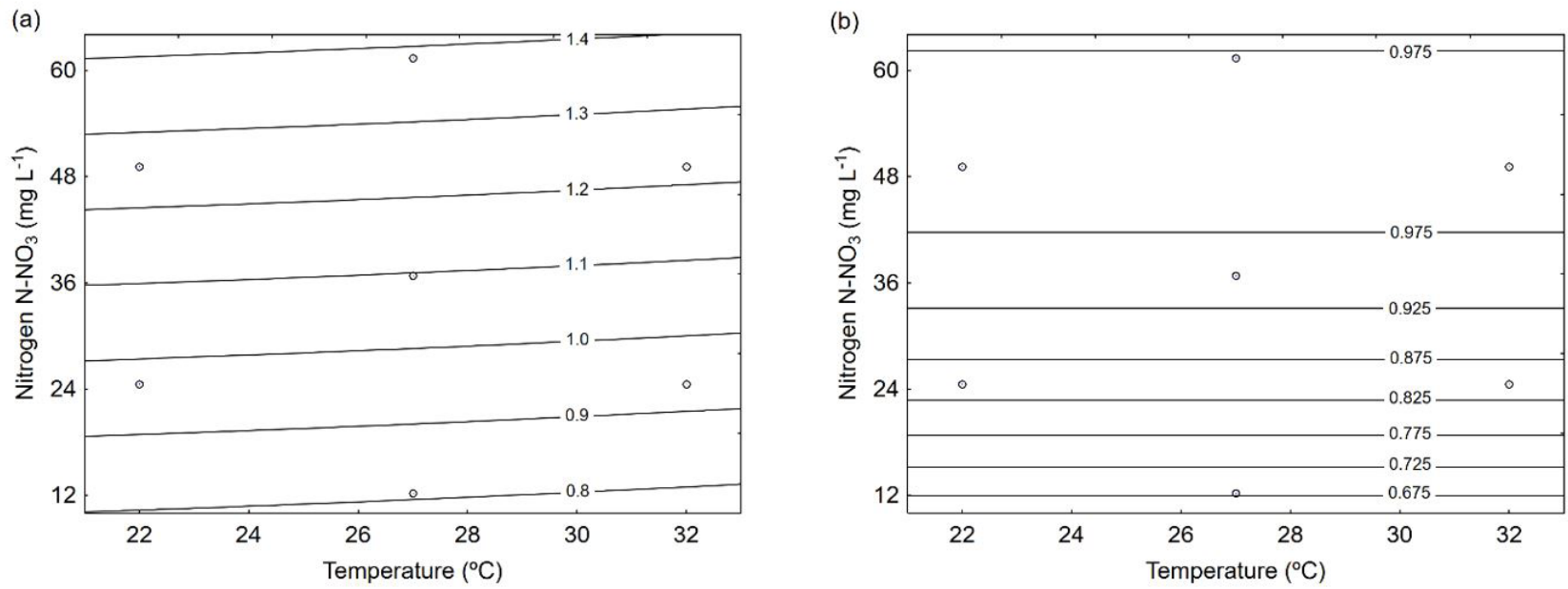

Figure 4. Response surfaces for (a) xanthophyll $\left(\mathrm{mg} \mathrm{g}^{-1}\right)$ and (b) carotene $\left(\mathrm{mg} \mathrm{g}^{-1}\right)$ contents in the biomass of H. luteoviridis grown under different temperatures and nitrogen concentrations. 
$\mathrm{g}^{-1}$ of biomass, respectively. The all-trans- $\beta$-carotene content showed little variation among the tested conditions, while the all-trans- $\alpha$-carotene increased with nitrogen concentration.

The highest values found for all-trans-lutein and all-trans-zeaxanthin were $0.77 \mathrm{mg} \mathrm{g}^{-1}$ and $0.39 \mathrm{mg} \mathrm{g}^{-1}$, respectively. The results indicate a strong negative effect of temperature on all-trans-zeaxanthin than on all-trans-lutein contents. Porphyridium purpureum biomass also showed high zeaxanthin content when cultured between $20^{\circ} \mathrm{C}$ and $22^{\circ} \mathrm{C}$ (Guihéneuf \& Stengel, 2015).

The positive effect of nitrogen on xanthophyll accumulation by $H$. luteoviridis could be linked to the positive effect of nitrogen on biomass growth, i.e., high xanthophylls content helps to keep protein synthesis in optimal growth conditions (Cordero et al., 2011). The results showed the possibility of increasing levels of lutein in the biomass by increasing the concentration of nitrogen in optimal growth conditions.

\section{Total fatty acids}

The qualitative profile of fatty acids of the microalgae H. luteoviridis was similar in all growth conditions (Table 2). The same fatty acids were also identified in other microalga species (Praveenkumar et al., 2012; Zhukova \& Aizdaicher, 1995). The changes in fatty acid composition were statistically analysed Tukey test. The saturated fatty acids (SFA) were about $50 \%$ of the total fatty acids, i.e., the hexadecanoic acid (C16:0) the major SFA identified in all culture conditions, followed by octadecanoic acid (C18:0); C16:0 content was higher at high temperatures and low nitrogen concentration, while C18:0 content increased at low temperatures and high nitrogen.

The monounsaturated fatty acids (MUFA) content ranged from $9.6 \%$ to $14.7 \%$ of the total fatty acids. The major MUFA was C18:1n-6, followed by C16:1n-9 and C18:1n9. The two formers were favoured at high temperatures, while C18:1n9 increased in the biomass cultured at low temperature.

The polyunsaturated fatty acids (PUFA) content ranged from $34.4 \%$ to $40.7 \%$ of total fatty acids. The essential fatty acids linoleic acid (LA, C18:2n-6) and $\alpha$-linolenic acid (ALA, C18:3n-3) constitute the major components of PUFAs. Other important PUFAs as eicosapentaenoic acid (EPA, C20:5n3) and docosahexaenoic acid (DHA 22:6n3) were also present among H. luteoviridis PUFAs. ALA and DHA synthesis were favored when cells grew at low temperatures, while LA was synthesized at high temperatures. The relationship between temperature and the contents of MUFAs and PUFAs may be explained by changes in the fluidity of the phospholipids of the cellular membrane layers, which depends on the unsaturation degree of the fatty acids. EPA content was

Table 2. Fatty acids composition of $H$. luteoviridis grown under different temperatures and nitrogen concentrations. ${ }^{*}$

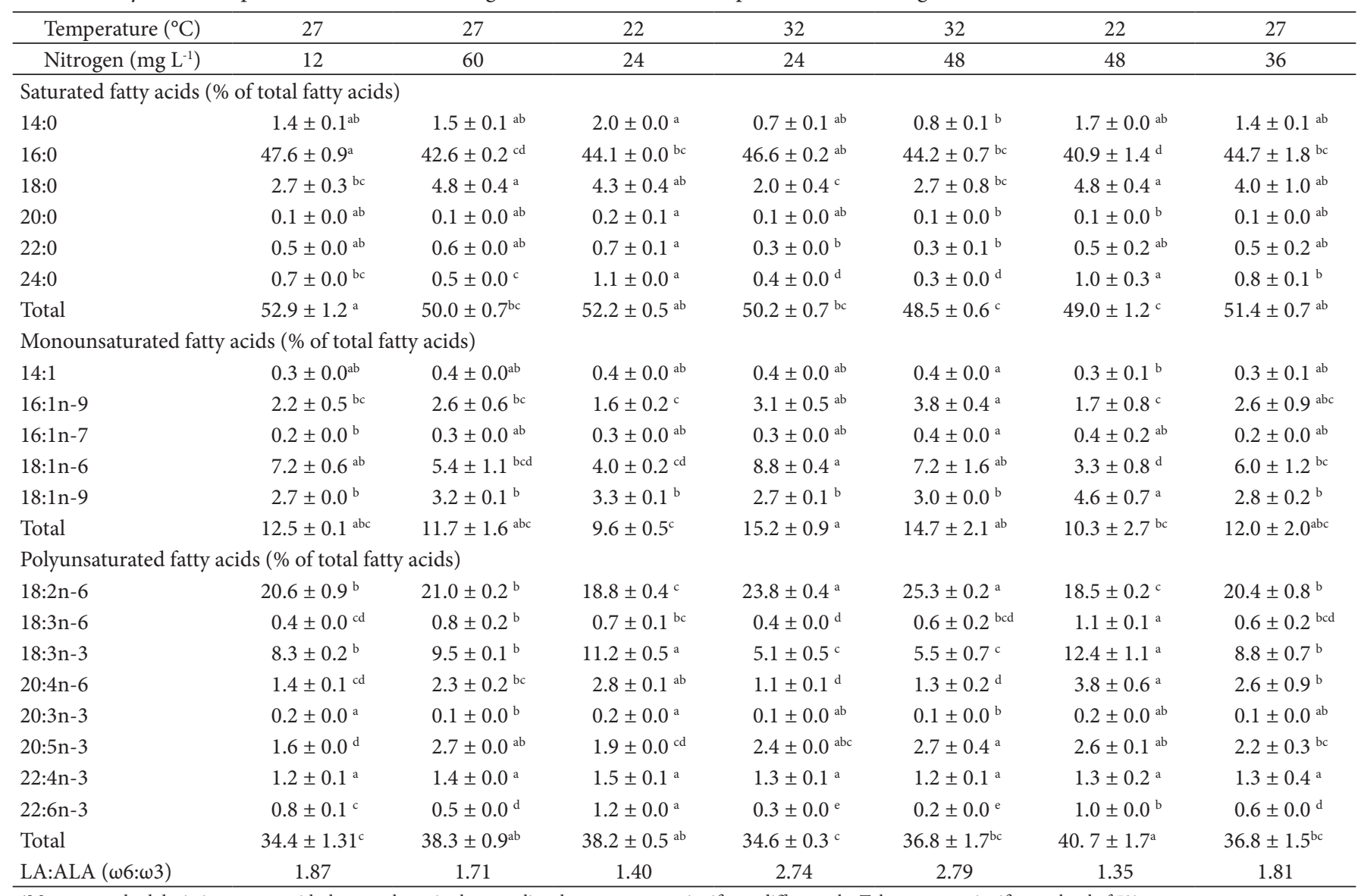

${ }^{\star}$ Mean \pm standard deviation; means with the same letter in the same line does not present significant difference by Tukey test at a significance level of $5 \%$. 
independent of the temperature and favoured when cells are cultured at high nitrogen concentrations.

The ingestion of omega 3 fatty acids ( $\omega 3$ ) such as ALA, EPA and DHA are associated with low incidence of myocardial infarction, chronic inflammation and autoimmune disorders and in high doses to cardiovascular diseases (Calder, 2008; Von Schacky, 2000; Simopoulos, 2002). LA is an essential omega 6 fatty acid $(\omega 6)$. Besides being rich in $\omega 3$ fatty acids, $H$. luteoviridis also showed a low $\omega 6: \omega 3$ ratio LA:ALA, (Table 2) around 2:1. A low $\omega 6: \omega 3$ ratio in diet was associated with a reduction of $45 \%$ in deaths from heart diseases, while the high $\omega 6: \omega 3$ ratio may increase the risk of inflammatory diseases (Russo, 2009; Simopoulos, 2002). Simopoulos (2004) reported an increase in $\omega 6$ consumption in recent decades, with an actual $\omega 6: \omega 3$ ratio ranging from 10:1 to $20: 1$. This increase in $\omega 6$ consumption is mainly linked to the use of vegetable oils (Bhattacharya et al., 2007; Calder, 2008).

\section{Conclusion}

In summary, Heterochlorella luteoviridis proved to be an important source of bioactive compounds such as xanthophylls, carotenes and polyunsaturated fatty acids. Our results show that it was possible to improve the growth conditions and, at the same time, induce the biosynthesis of these compounds of interest. High nitrogen concentration in culture medium induces biomass growth along with proteins, carotenoids and EPA biosynthesis. Although temperature did not affect biomass growth, low temperature induced $\omega 3$ fatty acids biosynthesis, such as ALA and DHA, and lowered $\omega 6: \omega 3$ ratio. As large-scale microalgae production shifts towards the use of photobioreactors instead of open systems, the careful control of growth conditions can be used to optimize microalgae production as well to enrich microalgae biomass with the target compounds.

\section{Acknowledgements}

The authors thank $\mathrm{CNPq}$ (National Concil of Scientific and Technological Development) and CAPES (Coordination for the Improvement of Higher Education) for the financial support.

\section{References}

Aksu, Z., \& Eren, A. T. (2005). Carotenoids production by the yeast Rhodotorula mucilaginosa: use of agricultural wastes as a carbon source. Process Biochemistry, 40(9), 2985-2991. http://dx.doi. org/10.1016/j.procbio.2005.01.011.

American Oil Chemists' Society - AOCS. (1997). Sampling and analysis of commercial fats and oils: AOCS official method Cc 6-25. Illinois: AOCS.

Bhattacharya, A., Sun, D., Rahman, M., \& Fernandes, G. (2007). Different ratios of eicosapentaenoic and docosahexaenoic omega-3 fatty acids in commercial fish oils differentially alter pro-inflammatory cytokines in peritoneal macrophages from C57BL/6 female mice. The Journal of Nutritional Biochemistry, 18(1), 23-30. PMid:16563716. http:// dx.doi.org/10.1016/j.jnutbio.2006.02.005.

Bligh, E. G., \& Dyer, W. J. (1959). A rapid method of total lipid extraction and purification. Canadian Journal of Biochemistry and Physiology, 37(8), 911-917. PMid:13671378. http://dx.doi.org/10.1139/o59-099.
Borowitzka, M. (1992). Algal biotechnology products and processes: matching science and economics. Journal of Applied Phycology, 4(3), 267-279. http://dx.doi.org/10.1007/BF02161212.

Buzzini, P., Martini, A., Gaetani, M., Turchetti, B., Pagnoni, U. M., \& Davoli, P. (2005). Optimization of carotenoid production by Rhodotorula graminis DBVPG 7021 as a function of trace element concentration by means of response surface analysis. Enzyme and Microbial Technology, 36(5-6), 687-692. http://dx.doi.org/10.1016/j. enzmictec.2004.12.028.

Calder, P. C. (2008). Polyunsaturated fatty acids, inflammatory processes and inflammatory bowel diseases. Molecular Nutrition \& Food Research, 52(8), 885-897. PMid:18504706. http://dx.doi. org/10.1002/mnfr.200700289.

Chacón-Lee, T. L., \& González-Mariño, G. E. (2010). Microalgae for "healthy" foods: possibilities and challenges. Comprehensive Reviews in Food Science and Food Safety, 9(6), 655-675. http://dx.doi. org/10.1111/j.1541-4337.2010.00132.x.

Chagas, A. L., Rios, A. O., Jarenkow, A., Marcilio, N. R., Ayub, M. A. Z., \& Rech, R. (2015). Production of carotenoids and lipids by Dunaliella tertiolecta using $\mathrm{CO}_{2}$ from beer fermentation. Process Biochemistry, 50(6), 981-988. http://dx.doi.org/10.1016/j.procbio.2015.03.012.

Champenois, J., Marfaing, H., \& Pierre, R. (2014). Review of the taxonomic revision of Chlorella and consequences for its food uses in Europe. Journal of Applied Phycology, 27(5), 1845-1851. http:// dx.doi.org/10.1007/s10811-014-0431-2.

Chen, C.-Y., Yeh, K.-L., Aisyah, R., Lee, D.-J., \& Chang, J.-S. (2011). Cultivation, photobioreactor design and harvesting of microalgae for biodiesel production: a critical review. Bioresource Technology, 102(1), 71-81. PMid:20674344. http://dx.doi.org/10.1016/j. biortech.2010.06.159.

Cheng, J., Huang, Y., Feng, J., Sun, J., Zhou, J., \& Cen, K. (2013). Improving $\mathrm{CO}_{2}$ fixation efficiency by optimizing Chlorella PY-ZU1 culture conditions in sequential bioreactors. Bioresource Technology, 144(0), 321-327. PMid:23891832. http://dx.doi.org/10.1016/j. biortech.2013.06.122.

Christaki, E., Bonos, E., Giannenas, I., \& Florou-Paneri, P. (2013). Functional properties of carotenoids originating from algae. Journal of the Science of Food and Agriculture, 93(1), 5-11. PMid:23044813. http://dx.doi.org/10.1002/jsfa.5902.

Converti, A., Casazza, A. A., Ortiz, E. Y., Perego, P., \& Del Borghi, M. (2009). Effect of temperature and nitrogen concentration on the growth and lipid content of Nannochloropsis oculata and Chlorella vulgaris for biodiesel production. Chemical Engineering and Processing, 48(6), 1146-1151. http://dx.doi.org/10.1016/j.cep.2009.03.006.

Cordero, B. F., Obraztsova, I., Couso, I., Leon, R., Vargas, M. A., \& Rodriguez, H. (2011). Enhancement of lutein production in Chlorella sorokiniana (Chorophyta) by improvement of culture conditions and random mutagenesis. Marine Drugs, 9(9), 1607-1624. PMid:22131961. http://dx.doi.org/10.3390/md9091607.

Doehlert, D. H. (1970). Uniform shell designs. Applied Statistics, 19(3), 231-239. http://dx.doi.org/10.2307/2346327.

DuBois, M., Gilles, K. A., Hamilton, J. K., Rebers, P. A., \& Smith, F. (1956). Colorimetric method for determination of sugars and related substances. Analytical Chemistry, 28(3), 350-356. http://dx.doi. org/10.1021/ac60111a017.

Fan, J., Yan, C., Andre, C., Shanklin, J., Schwender, J., \& Xu, C. (2012). Oil accumulation is controlled by carbon precursor supply for fatty acid synthesis in Chlamydomonas reinhardtii. Plant \& Cell Physiology, 53(8), 1380-1390. PMid:22642988. http://dx.doi.org/10.1093/pcp/ pcs082. 
Guihéneuf, F., \& Stengel, D. B. (2015). Towards the biorefinery concept: interaction of light, temperature and nitrogen for optimizing the co-production of high-value compounds in Porphyridium purpureum. Algal Research, 10, 152-163. http://dx.doi.org/10.1016/j. algal.2015.04.025.

Guillard, R. L. (1975). Culture of phytoplankton for feeding marine invertebrates. In W. Smith \& M. Chanley (Eds.), Culture of marine invertebrate animals (pp. 29-60). New York: Plenum Press. http:// dx.doi.org/10.1007/978-1-4615-8714-9.

Ho, S.-H., Chen, C.-Y., \& Chang, J.-S. (2012). Effect of light intensity and nitrogen starvation on $\mathrm{CO}_{2}$ fixation and lipid/carbohydrate production of an indigenous microalga Scenedesmus obliquus CNW-N. Bioresource Technology, 113, 244-252. PMid:22209130. http://dx.doi.org/10.1016/j.biortech.2011.11.133.

Hultberg, M., Jönsson, H. L., Bergstrand, K.-J., \& Carlsson, A. S. (2014). Impact of light quality on biomass production and fatty acid content in the microalga Chlorella vulgaris. Bioresource Technology, 159, 465467. PMid:24718357. http://dx.doi.org/10.1016/j.biortech.2014.03.092.

Ikaran, Z., Suárez-Alvarez, S., Urreta, I., \& Castañón, S. (2015). The effect of nitrogen limitation on the physiology and metabolism of Chlorella vulgaris var L3. Algal Research, 10, 134-144. http://dx.doi. org/10.1016/j.algal.2015.04.023.

Jarenkow, A., Steckert, E. V., Roman, G., Chagas, A. L., \& Rech, R. (2015). Adição de $\mathrm{NaNO}_{3}$ em etapas no cultivo da microalga Chlorella sp. In Proceedings of the XX Congresso Brasileiro de Engenharia Química. Florianópolis: Blucher. Retrieved from http://www.proceedings. blucher.com.br/article-details/adio-de-nano3-em-etapas-no-cultivoda-microalga-chlorella-sp-16674

Jin, E., Polle, J. E. W., Lee, H. K., Hyun, S. M., \& Chang, M. (2003). Xanthophylls in microalgae: From biosynthesis to biotechnological mass production and application. Journal of Microbiology and Biotechnology, 13(2), 165-174. Retrieved from http://www.koreascience. or.kr/article/ArticleFullRecord.jsp?cn=E1MBA4_2003_v13n2_165

Joseph, J. D., Ackman, R. G., Joseph, J., Ackman, R., Joseph, J. D., \& Ackman, R. G. (1992). Capillary column gas chromatographic method for analysis of encapsulated fish oils and fish oil ethyl esters: collaborative study. Journal of AOAC International, 73(3), 488-506. Retrieved from http://cat.inist.fr/?aModele=afficheN\&c psidt $=4924968$

Juneja, A., Ceballos, R. M., \& Murthy, G. S. (2013). Effects of environmental factors and nutrient availability on the biochemical composition of algae for biofuels production: a review. Energies, 6(9), 4607-4638. http://dx.doi.org/10.3390/en6094607.

Kochem, L. H., Da Fré, N. C., Redaelli, C., Rech, R., \& Marcílio, N. R. (2014). Characterization of a novel flat-panel airlift photobioreactor with an internal heat exchanger. Chemical Engineering \& Technology, 37(1), 59-64. http://dx.doi.org/10.1002/ceat.201300420.

Li, D., Wang, L., Zhao, Q., Wei, W., \& Sun, Y. (2015). Improving high carbon dioxide tolerance and carbon dioxide fixation capability of Chlorella sp. by adaptive laboratory evolution. Bioresource Technology, 185, 269-275. PMid:25776894. http://dx.doi.org/10.1016/j. biortech.2015.03.011.

Lowry, O. H., Rosebrough, N. J., Farr, A. L., \& Randall, R. J. (1951). Protein measurement with the folin phenol reagent. The Journal of Biological Chemistry, 193(1), 265-275. PMid:14907713.

Mandelli, F., Miranda, V., Rodrigues, E., \& Mercadante, A. (2012). Identification of carotenoids with high antioxidant capacity produced by extremophile microorganisms. World Journal of Microbiology \& Biotechnology, 28(4), 1781-1790. PMid:22805960. http://dx.doi. org/10.1007/s11274-011-0993-y.
Markou, G., \& Nerantzis, E. (2013). Microalgae for high-value compounds and biofuels production: A review with focus on cultivation under stress conditions. Biotechnology Advances, 31(8), 1532-1542. PMid:23928208. http://dx.doi.org/10.1016/j.biotechadv.2013.07.011.

Metting, B., \& Pyne, J. W. (1986). Biologically active compounds from microalgae. Enzyme and Microbial Technology, 8(7), 386-394. http:// dx.doi.org/10.1016/0141-0229(86)90144-4.

Neustupa, J., Němcová, Y., Eliáš, M., \& Škaloud, P. (2009). Kalinella bambusicola gen. et sp. nov. (Trebouxiophyceae, Chlorophyta), a novel coccoid Chlorella-like subaerial alga from Southeast Asia. Phycological Research, 57(3), 159-169. http://dx.doi.org/10.1111/ j.1440-1835.2009.00534.x.

Olofsson, M., Lamela, T., Nilsson, E., Bergé, J.-P., del Pino, V., Uronen, P., \& Legrand, C. (2014). Combined effects of nitrogen concentration and seasonal changes on the production of lipids in Nannochloropsis oculata. Marine Drugs, 12(4), 1891-1910. PMid:24691025. http:// dx.doi.org/10.3390/md12041891.

Orset, S., \& Young, A. J. (1999). Low-temperature-induced synthesis of alpha-carotene in the microalga Dunaliella salina (Chorophyta). Journal of Phycology, 35(3), 520-527. http://dx.doi.org/10.1046/j.15298817.1999.3530520.x.

Pancha, I., Chokshi, K., George, B., Ghosh, T., Paliwal, C., Maurya, R., \& Mishra, S. (2014). Nitrogen stress triggered biochemical and morphological changes in the microalgae Scenedesmus sp. CCNM 1077. Bioresource Technology, 156, 146-154. PMid:24495540. http:// dx.doi.org/10.1016/j.biortech.2014.01.025.

Perez-Garcia, O., \& Bashan, Y. (2015). Microalgal heterotrophic and mixotrophic culturing for bio-refining: from metabolic routes to techno-economics. In A. Prokop, R. K. Bajpai, \& M. E. Zappi (Eds.), Algal biorefineries (Products and Refinery Design, Vol. 2, pp. 61-131). Cham: Springer International Publishing. http://dx.doi. org/10.1007/978-3-319-20200-6_3.

Perez-Garcia, O., De-Bashan, L. E., Hernandez, J. P., \& Bashan, Y. (2010). Efficiency of growth and nutrient uptake from wastewater by heterotrophic, autotrophic, and mixotrophic cultivation of Chlorella vulgaris immobilized with Azospirillum brasilense. Journal of Phycology, 46(4), 800-812. http://dx.doi.org/10.1111/j.1529-8817.2010.00862.x.

Praveenkumar, R., Shameera, K., Mahalakshmi, G., Akbarsha, M. A., \& Thajuddin, N. (2012). Influence of nutrient deprivations on lipid accumulation in a dominant indigenous microalga Chlorella sp., BUM11008: Evaluation for biodiesel production. Biomass and Bioenergy, 37, 60-66. http://dx.doi.org/10.1016/j.biombioe.2011.12.035.

Pulz, O., \& Gross, W. (2004). Valuable products from biotechnology of microalgae. Applied Microbiology and Biotechnology, 65(6), 635648. PMid:15300417. http://dx.doi.org/10.1007/s00253-004-1647-x.

Renaud, S. M., Thinh, L.-V., Lambrinidis, G., \& Parry, D. L. (2002). Effect of temperature on growth, chemical composition and fatty acid composition of tropical Australian microalgae grown in batch cultures. Aquaculture, 211(1-4), 195-214. http://dx.doi.org/10.1016/ S0044-8486(01)00875-4.

Rodrigues, D. B., Flores, É. M. M., Barin, J. S., Mercadante, A. Z., Jacob-Lopes, E., \& Zepka, L. Q. (2014). Production of carotenoids from microalgae cultivated using agroindustrial wastes. Food Research International, 65, 144-148. http://dx.doi.org/10.1016/j. foodres.2014.06.037.

Rosso, V. V., \& Mercadante, A. Z. (2007). Identification and quantification of carotenoids, by HPLC-PDA-MS/MS, from Amazonian fruits. Journal of Agricultural and Food Chemistry, 55(13), 5062-5072. http://dx.doi.org/10.1021/jf0705421.

Russo, G. L. (2009). Dietary n-6 and n-3 polyunsaturated fatty acids: from biochemistry to clinical implications in cardiovascular prevention. 
Biochemical Pharmacology, 77(6), 937-946. PMid:19022225. http:// dx.doi.org/10.1016/j.bcp.2008.10.020.

Saha, S. K., Moane, S., \& Murray, P. (2013). Effect of macro- and micro-nutrient limitation on superoxide dismutase activities and carotenoid levels in microalga Dunaliella salina CCAP 19/18. Bioresource Technology, 147, 23-28. PMid:23981270. http://dx.doi. org/10.1016/j.biortech.2013.08.022.

Sahu, A., Pancha, I., Jain, D., Paliwal, C., Ghosh, T., Patidar, S., Bhattacharya, S., \& Mishra, S. (2013). Fatty acids as biomarkers of microalgae. Phytochemistry, 89, 53-58. PMid:23453131. http:// dx.doi.org/10.1016/j.phytochem.2013.02.001.

Schroeder, W. A., \& Johnson, E. A. (1995). Singlet oxygen and peroxyl radicals regulate carotenoid biosynthesis in Phaffia rhodozyma. The Journal of Biological Chemistry, 270(31), 18374-18379. PMid:7629161. http://dx.doi.org/10.1074/jbc.270.31.18374.

Simopoulos, A. P. (2002). Omega-3 fatty acids in inflammation and autoimmune diseases. Journal of the American College of Nutrition, 21(6), 495-505. PMid:12480795. http://dx.doi.org/10.1080/073157 24.2002.10719248.

Simopoulos, A. P. (2004). Omega-6/Omega-3 essential fatty acid ratio and chronic diseases. Food Reviews International, 20(1), 77-90. http://dx.doi.org/10.1081/FRI-120028831.

Singh, P., Guldhe, A., Kumari, S., Rawat, I., \& Bux, F. (2015). Investigation of combined effect of nitrogen, phosphorus and iron on lipid productivity of microalgae Ankistrodesmus falcatus KJ671624 using response surface methodology. Biochemical Engineering Journal, 94, 22-29. http://dx.doi.org/10.1016/j.bej.2014.10.019.

Singh, S. P., \& Singh, P. (2015). Effect of temperature and light on the growth of algae species: A review. Renewable \& Sustainable Energy Reviews, 50, 431-444. http://dx.doi.org/10.1016/j.rser.2015.05.024.
Sushchik, N. N., Kalacheva, G. S., Zhila, N. O., Gladyshev, M. I., \& Volova, T. G. (2003). A temperature dependence of the intra- and extracellular fatty-acid composition of green algae and cyanobacterium. Russian Journal of Plant Physiology: a Comprehensive Russian Journal on Modern Phytophysiology, 50(3), 374-380. http://dx.doi. org/10.1023/A:1023830405898.

Venkata Mohan, S., \& Devi, M. P. (2014). Salinity stress induced lipid synthesis to harness biodiesel during dual mode cultivation of mixotrophic microalgae. Bioresource Technology, 165, 288-294. PMid:24709529. http://dx.doi.org/10.1016/j.biortech.2014.02.103.

Von Schacky, C. (2000). n-3 fatty acids and the prevention of coronary atherosclerosis. The American Journal of Clinical Nutrition, 71(1, Suppl), 224-227. PMid:10617975.

Wang, H.-T., Yao, C.-H., Ai, J.-N., Cao, X.-P., Xue, S., \& Wang, W. (2014). Identification of carbohydrates as the major carbon sink of the marine microalga Isochrysis zhangjiangensis (Haptophyta) and optimization of its productivity by nitrogen manipulation. Bioresource Technology, 171, 298-304. PMid:25216035. http://dx.doi. org/10.1016/j.biortech.2014.08.090.

Zhu, S., Huang, W., Xu, J., Wang, Z., Xu, J., \& Yuan, Z. (2014). Metabolic changes of starch and lipid triggered by nitrogen starvation in the microalga Chlorella zofingiensis. Bioresource Technology, 152, 292-298. PMid:24308944. http://dx.doi.org/10.1016/j.biortech.2013.10.092.

Zhu, S., Wang, Y., Shang, C., Wang, Z., Xu, J., \& Yuan, Z. (2015). Characterization of lipid and fatty acids composition of Chlorella zofingiensis in response to nitrogen starvation. Journal of Bioscience and Bioengineering, 120(2), 205-209. PMid:25782619. http://dx.doi. org/10.1016/j.jbiosc.2014.12.018.

Zhukova, N. V., \& Aizdaicher, N. A. (1995). Fatty acid composition of 15 species of marine microalgae. Phytochemistry, 39(2), 351-356. http://dx.doi.org/10.1016/0031-9422(94)00913-E. 
Appendix A. Supplemental figure.

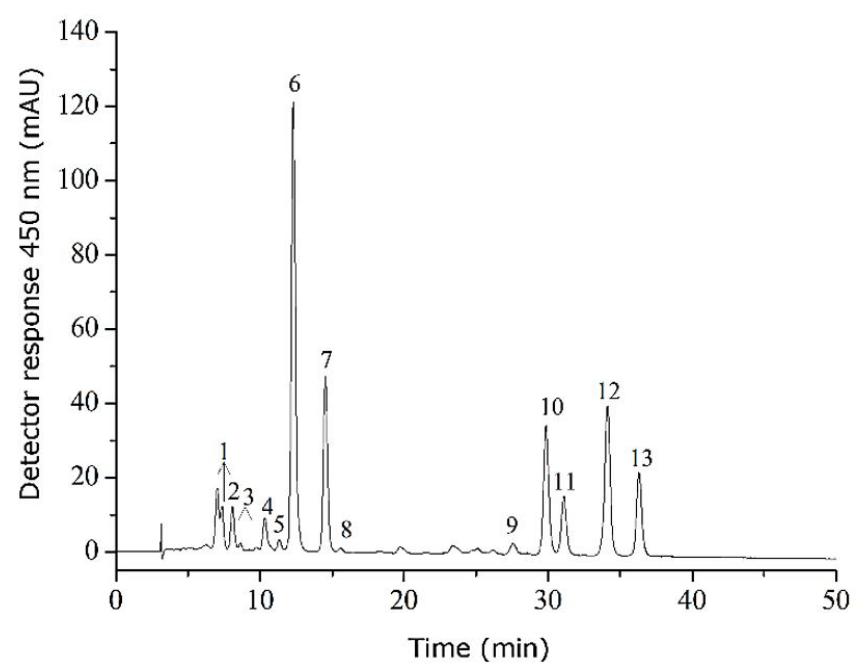

Figure A1. Chromatogram obtained by HPLC-MS of carotenoids from H. luteoviridis. ${ }^{* 1}$ all-trans-violaxantin, ${ }^{2}$ cis-violaxanthin, ${ }^{3} 13$-cis-lutein, ${ }^{4} 13^{\prime}$-cis-lutein, ${ }^{5}$ all-trans-lutein, ${ }^{6}$ all-trans-zeaxanthin, ${ }^{7} 15$-cis- $\beta$-caroteno, ${ }^{8}$ all- trans- $\alpha$-caroteno, ${ }^{9} 13$-cis- $\beta$-caroteno, ${ }^{10}$ all-trans- $\beta$-carotene, ${ }^{11}$ 9-cis- $\beta$-caroteno. 